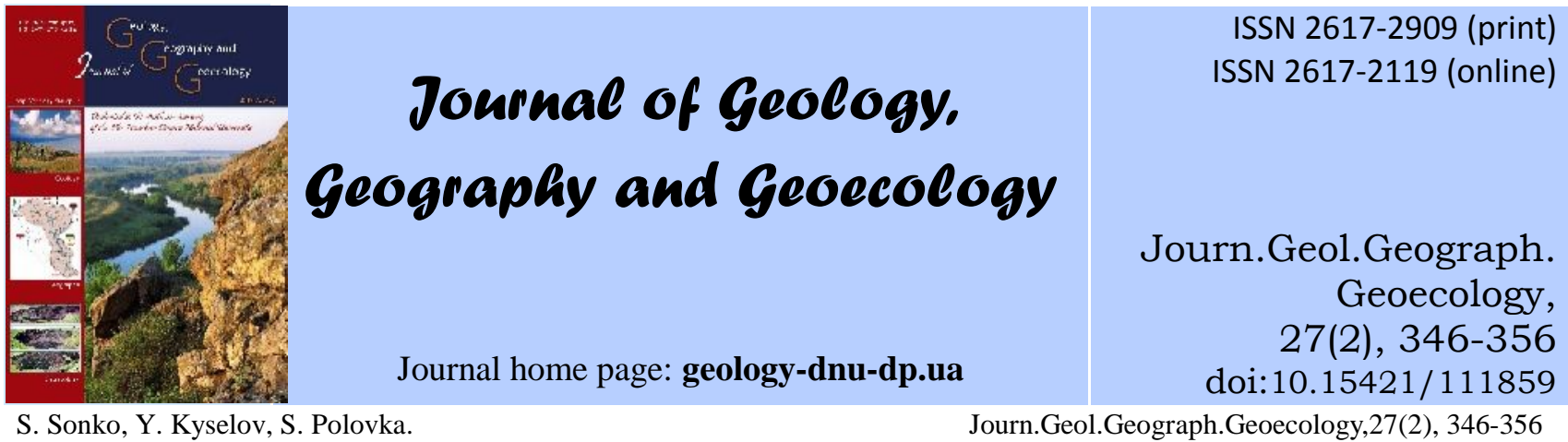

\title{
On the modern conception of environment
}

\author{
${ }^{1}$ S. Sonko, ${ }^{1}$ Yu. Kyselov, ${ }^{2}$ S. Polovka \\ ${ }^{1}$ Uman National University of Horticulture, Uman, Ukraine, e-mail: Sp.sonko@gmail.com \\ ${ }^{2}$ Uman State Pedagogical University named after Pavlo Tychyna, Uman, Ukraine, e-mail:sergi_polovka@ukr.net
}

Received 15.06.2018;

Received in revised form 05.07.2018;

Accepted 23.07.2018

Abstract. Currently a large number of, geographers and representatives of related sciences claim to have created integrated environmental concepts. This applies, in particular, to the concepts of "environmental science", "sociogeosystems", "anthropogenic landscape", "eco-geosophia", etc. All of them confirm the importance of solving the global environmental problem, and the need to unite scholars in all specialties. There is a significant revival of interest in the integral essence of geography, especially among anthropogeographers. This testifies to the fundamental unity of geographical science without its distinct division into natural and social geography, which divides the discipline up into a plethora of specific objects and subjects. Anthropogeographers have come to understand that the earth's space was initially organized by Nature itself. Mankind from the Neolithic Age has transformed his use of nature into the noosphere. If before the Neolithic revolution there still existed natural landscapes on the surface of the planet , then the Neolithic populations of Homo sapiens started to actively change the environments they inhabited. Approximately then, the search for ways to justify such, often destructive, intervention began. Such a change in the landscape was brought about by man, which encouraged scientists unwittingly to develop an "intentional paradigm", according to which the methodology of each science tries to take into account the role of man not only as a component of nature, but as its researcher. Even Strabo having realized the many-sidedness of human existence on our planet, already in ancient times, considered himself "not a geographer, not a historian, but a philosopher." Hettner, with his idea of "embedding" into the earth's space of all things, considered the object of studying geography this very earthly space with objects and phenomena that filled it and interacted with each other. According to Hettner, the connections between them have a landscape causal nature. To such systems of geobjects, Hettner also related human society. The idea of "through" was found in the works of our contemporary physicist and geographer Aleksey Reteyum, who discovered integral (socio-natural) spatial entities on the surface of the planet ("choriones" and "sphragids"), once again proving the "right to exist" of the noosphere suggested by Volodymyr Vernadsky. At present, it is geographers who must create an adequate concept of the environment, which is not yet developed in completed form. Its final design will require the rejection of the mechanistic perception of the world, divided into objects and subjects of research. It is geographers who should identify in time and space such integrated environmental systems (socio-natural systems, whose subsystems can be natural landscape systems and sociogeosystems), which are shaped as a result of the joint development of nature and society. Prospects for the productive development of environmental science are related to the concept of noosphere ecosystems.

Keywords: environment, noosphere, anthropogenic landscape, intentional paradigm, socio-natural systems.

\section{ро суч сну концепцію довкілля}

\author{
. онько*, . исельов*, . оловк ** \\ * м нський н ціон льний університет с дівництв , м нь, кр їн, e-mail: Sp.sonko@gmail.com \\ ** м нський держ вний пед гогічний університет імені вл ичини, м нь, кр їн, \\ e-mail:sergi_polovka@ukr.net
}

нот ція. исленні суч сні концепції довкілля ч сто претендують н інтегр льність. е стосується, зокрем , концепцій «середовищезн вств », «соціогеосистем», «нтропогенного л ндш фту», «екогеософії» тощо. н ковим є відродження інтересу до інтегр льної сутності геогр фії с ме серед нтропогеогр фів, що свідчить про принципову єдність геогр фічної н уки. нтропогеогр фи поступово доходять розуміння того, що земний простір від поч тку був орг нізов ний с мою риродою. юдство ще з неоліту здійснює н емлі ноосферне природокористув ння. кщо до неолітичної революції н денній поверхні пл нети ше існув ли природні л ндш фти, то з неоліту популяція оmo sapiens почин $є$ їх ктивно змінюв ти. риблизно тоді ж поч лись пошуки способів випр вд ння т кого, ч сто руйнівного, втруч ння. к змінен до непізн в ності людиною л ндш фтн оболонк спонук л н уковців розробляти «інтенціон льну п р дигму», з якою методологія 
кожної н уки н м г ється вр хув ти роль людини не лише як скл дової природи, ле як її дослідник . ьогодні с ме геогр ф м н лежить створити декв тну дійсності концепція довкілля, як в з вершеному вигляді поки що не розроблен . ї ост точне оформлення вим г тиме відмови від мех ністичного сприйняття н вколишнього світу, поділеного н об'єкти і предмети дослідження. ме геогр ф м н лежить позн чити в ч сі й у просторі т кі інтегр тивні системи н вколишнього середовищ (соціоприродні системи, підсистем ми яких можуть бути природні л ндш фтні системи у різному ступені змінені людиною), які утворені в результ ті спільного розвитку природи і суспільств . ерспективи продуктивного розвитку н уки про довкілля (довкіллєзн вств ) пов'яз ні з концепцією ноосферних екосистем.

лючові слов : довкілля, ноосфер, нтропогенний л ндш фт, інтенціон льн $n$ р дигм, соціоприродні системи.

Introduction. The article is the continuation of the discussion about the concept of the environment, which once again (after V. Nikolayev (Nikolayev, 2006), V. Nekos (Nekos, Nekos, Safranov, 2011),

. Holubets (Holubets, 2015), O. Kovalyov (Kovalyov, 2014), H. Denysyk (Denysyk, 2001) and others) was carried on in the article by O. Topchiev, D. Malchykova, I. Pylypenko and V. Yavorska (Topchiev, Malchykova, Pylypenko, Yavorska, 2017).

The very fact that the article was published in 'Ukrainian Geographic Journal' in the section 'Call for Discussion', testifies to the extraordinary urgency of this problem. It is noteworthy that this section in UGJ reminds one of an old trap, which the editorial board regularly walks into, however, it always appears on its way. Indeed, there have been more than 10-15 articles dealing with the problem in this section since the mid-1990s (V. Pashchenko, I. Chervaniov, O. Kovalyov, O. Topchiev, M. Holubets, L. Rudenko, M. Bagrov, S. Sonko, etc.). In spite of the fact that the national geographic establishment openly neglects methodological problems of geography, it (the methodology) nevertheless makes its way up above the ground, like shoots that lean towards the sun. This is confirmed by all attempts to develop a single concept of the environment. Such attempts testify to the fact that this problem can gradually move most other problems in the subject area of many sciences to the background. The processes associated with this were noticed by V. Vernadsky ${ }^{1}$ and emphasized by one of the authors in the early 2000 s (Sonko, 2003).

The fact that the authors of the abovementioned article are anthropogeographers (representatives of economic, or, broadly speaking, social geography) is really significant. Perhaps the revival of in-terest in the integral essence of geography among anthropogeographers marks the transition of

\footnotetext{
'Nowadays, the framework of individual sciences, which scientific knowledge is streamed into cannot accurately determine the area of the scientific idea of a researcher and exactly describe his scientific effort. The problems that are of interest to him often do not fit into the framework of an individual, well-formed science. We specialize not in sciences but in problems' (Vernadsky, 1991).
}

this science to a qualitatively new (old $\left.?^{2}\right)$ level of interpretation of reality. This is obvious to a great extent, since the monographic study of both the centre and periphery relations (Pylypenko, 2015) and the basics of geo-planning (Topchiev, 2014) once would certainly have led the authors to understanding the integral properties of the Earth's space - without dividing it into 'the objects the study' of natural geographers and anthropogeographers geospheres (Topchiev, Malchykova, Pylypenko, Yavorska, 2017), and without its vague attribution to 'the subject area' of either social or natural geography (Topchiev, 2004). The present-day fragmentation of geography, which used to be integral, is sometimes absurd. One may visit the site of 'Bibliometrics of Ukrainian Science'. In the section 'Earth Sciences' only the scientific preferences of physiographers (mainly geography and cartography, or the environment) (T. Bobra, M. Hrodzynskyi, H. Denysyk, I. Kovalchuk, etc.) are more or less adequately given an account of. As for economic geographers, perhaps only $\mathrm{O}$. Topchiev appeared in the section 'Geography and Cartography' in the branch called 'Social Sciences". The rest of the representatives of this modern geography branch are at best marked as 'Geography and Cartography'. Most scientists are referred to the purely natural 'Earth Sciences', 'Environmental Sciences' and 'Ecology'. As a result, it gives an impression of the inappropriateness of 'discrimination' of both social and public geography.

We are convinced that it is anthropogeographers who have to be most concerned about the problem of the integral nature of the Earth's space.

\footnotetext{
${ }^{2}$ Did not the classic of economic geography N. Baransky in the 30 s of the twentieth century urge that a territory (of a country or a region, etc.) be considered as a complex 'from geology to ideology'? Was not it our compatriot Serhiy Podolynskyi in the 19th century who emphasized the energetic essence of all economic processes, thus trying to implement truly objective (physical and economic) pricing mechanisms for goods and services in the world economic system? Taking into account the fact that it is economics and economic sciences that are the leaders in a complex system of developing natural resources of the planet (including its landscape envelope), it may be more appropriate to call oneself an economic geographer, rather than a social geographer or public geographer.
} 
Eventually, these scientists will realize that the Earth's space from the very beginning was appropriately or-ganized by Nature itself. Various terms have been suggested for the interpretation of the Earth's space itself and its individual fragments, as well as for the science that would conduct its integrated study. In particular, various aspects of existence of the Earth's space today are explored in the context of the concepts of sociogeosystems (Nemets, Nemets, 2014), environmental studies (Holubets, 2015), neoecology (Nekos, Nekos, Safranov, 2011), anthropogenic landscape (Denysyk, 2001), intentional paradigm (Topchiev, Nudelman, Rudenko, 2012), ecogeosophy (Kyselov, 2015), etc.

In fact, the recent intensive growth of the debate on environmental studies also has another root - the civilizational one. There is an inevitable question that geographers of the anthropogenic and landscape branch (Yablokov, Levchenko, 2015) face today, in the era of radical man-made changes in the biosphere, - is it still safe to further 'scientifically justify' the change of natural landscapes by man? Is this safe as long as such 'scientific justification' gives a powerful tool to 'constructors' of the 'mining', 'uranium' and other landscapes for further human attacks on nature (Sonko, Maksymenko, 2016).

Material and methods of research. The research is based on the elucidation of the main provisions of the existing concepts of environmental studies that have features of integrity with respect to the natural sciences, the theoretical foundations of which lie in their basis.

In the course of the research, mostly philosophical and general scientific methods were used, including the logical ones (analysis, synthesis, comparison, deduction, induction), as well as dialectics.

The analysis was implemented at each stage of the research. When considering different concepts, their objects were determined and the content characterized, geographical and ecological components were compared. Synthesis, which is the dialectical opposite of analysis and is logically applied after the latter, consists in highlighting the common features of different environmental concepts that can form the basis of the integrated environmental study concept. Comparison of the analysed scientific constructions is an indispensable tool for extracting their common or similar elements.

The study used the deductive and inductive methods. In particular, the deduction manifests itself in taking the idea of creating an integrated environmental study concept as a starting point, and each item of individual natural science concepts was characterized in terms of its conformity with the general purpose of our research. The induction reveals itself in the selection of such provisions of each scientific construction, which can become 'building material' for the creation of an integrated concept of the environment.

Dialectics as a philosophical method is present in the research due to the application of the laws of unity and struggle of opposites (through a combi-nation of analysis and synthesis, deduction and induction), and the transition of quantitative changes to qualitative ones (due to the gradual accumulation of individual concepts in natural science, which, taken together, give the necessary facts and scientific provisions for the construction of an integrated concept of the geographic and environmental study).

The research made use of the historical method, in particular, when analysing the development of environmental ideas in time (from the noosphere by V. Vernadsky up to environmental studies by M. Holubets).

Results and their analysis. Taking into account the unsuccessful attempts of non-geographers to solve a purely geographical problem (the concept of 'environmental studies' by M. Holubets), one of the authors, considering himself to be an economic geographer (not even a social or a public geographer), solved this problem for himself 15 years ago (Sonko, 2003).

In fact, humanity has for a long time (approximately from the Neolithic period) exercised nature management of the noosphere on our planet. But if, before the Neolithic revolution, there had been natural landscapes on its daylight surface, after it Homo sapiens started to actively modify them, 'building himself' into the landscape envelope and forming anthropogenic landscape strips such as a 'forest field' (Denysyk, 2001) with ecotones - without explicit boundaries of natural zones. Approximately at that time, the search for the ways to justify such intervention, which was often destructive, began. Thus, in recent years, the landscape envelope, unrecognizably changed by man, has prompted scientists to develop an intentional paradigm', according to which the methodology of each science tries to take into account the role of man not only as a component of nature, but as a researcher who creates different branches of knowledge and sets respective subjective target guides for them (Topchiev, Nudelman, Rudenko, 2012). In our opinion, this is an obvious step back, as this emphasizes the return to the object-object relations between man and nature, which most modern landscape scientists (M. D. Hrodzynsky) rejected long ago in favour of the post-classical subject-subject ones (Maksymenko, 2018). 
Therefore, the idea of the noosphere (almost two thousand years before the term appeared) 'embedded' in the Earth's atmosphere, has embarrassed geographers from the times this science appeared. Thus Strabo, the author of the world-famous ' $\mathrm{Ge}$ ography', understanding the many-sidedness of human existence on our planet, even in ancient times, considered himself to be 'not a geographer, not a histo-rian, but a philosopher' (Arsky, 2015). A. Hettner, with his idea of 'embedding' all things in existence into the Earth's space, considered this very earthly space with all the objects and phenomena present in it and interacting with each other to be the object of geographical studies. The links among them, according to A. Hettner, have a landscape, causal nature. A. Hettner also referred human society to similar systems of geo-objects. Some unique combinations of certain objects and phenomena in a particular territory lead to the emergence of geographic countries (choros, space) (Hettner, 1927).

However, the idea of 'transversality' was fully elucidated in the book by our contemporary $\mathrm{O}$. Reteyum 'The Earth's Worlds'. He 'discovered' integrative (socio-natural) spatial entities ('chorions' and 'sphragis') on the daylight surface of the planet (the term by O. Kovalyov) and once again proved the right of the noosphere as defined by $\mathrm{V}$. Vernadsky to exist. At the same time, being a physical geographer, O. Reteyum was constantly reinforcing this idea by examples of consortium relations in 'pure' (without humans) nature (Reteyum, 1988).

Dozens (or even hundreds) of scientists (not only geographers) can be listed as those who have come up with an idea of the integrity of the planetary structure (J. Lovelock, L. Margulis, V. Gorshkov, etc.). This idea turned out to be so obvious that even well-known movie makers (James Cameron, 'Avatar') succeeded in promoting it. Nevertheless, its real implementation into life, which gave rise to the 'strategy of sustainable development', in its twenties (Johannesburg, 2002) became deficient, which has been written about many times (Sonko, 2018).

The comprehension of the reclaimed Earth's space substantially transformed by the versatile activity of humans (at different levels - from the planetary up to the local level) is also carried out by ecogeosophy. The sources of ecogeosophy, which was founded at the end of the twentieth century, are 'classical' geosophy and modern ecology.

We used the epithet 'classical' in inverted comas with respect to geosophy, because even the age of this discipline - not only ecogeosophy — is less than a century. Geosophy is a philosophy of human space that explores spiritual aspects of the natural landscape's influence (conditionally, unchanged by man) on human communities, in particular ethnos. L. Gumilev considered ethnos to be a geographical, landscape phenomenon, and the landscape itself - its storage and nutritional medium (Gumilev, 2006). Consequently, geosophy is a science of landscape and ethnic interaction.

The synthesis of geosophy with modern ecology, which long ago evolved out of the former position of a branch of biology, becoming an independent science and, moreover, an extensive system of many bio-, geo-, socio- and technical ecological disciplines, is ecogeoseophy. If the scheme of geosophical regionalization of the Earth's space (Earthworld), based on the nature of landscapeethnic interaction (Kyselov, 2011) became the logical result of our geosophical research, then the peculiarities of human space caused by more or less significant changes in landscapes as a result of economic and other types of human activities should be taken into account when conducting ecogeosophic research. In particular, in terms of ecogeosophy, the Donbas appears to be not only and not so much in the Donets Territory, a fragment of the steppe landscape and an extrazonal island of the forest steppe in the steppe for the territory of Ukraine, and, above all, a region with a predominance of 'anthropogenic' (according to the terminology of one of the authors (Kyselov, 2017) landscapes proper. Thus, this region seems to be taken out of human space, becoming a virtually unfit environment for the life of the landscape predetermined human communities - ethnoses. The example of the Donbas illustrates the discrepancy of ecogeophysical realia, which we will later depict in the form of sketch maps as already mapped geosophical earth-spatial formations.

The post-classical approach to the formation of the ecological network can be the confirmation of the anthropogenic component of landscape development (especially for the regions of old industrial development). According to this approach, not only natural objects but also the man-made ones must be bequeathed today, (Sonko, Kazakova, 2016).

We present the analysis of the abovementioned modern environmental concepts, which more or less claim to be integral, in Table 1.

In our opinion, the main feature of all the environmental concepts analysed is their interdisciplinary nature. Mostly the tendencies for integration between geography and ecology (in particular, geosociosystemology, environmental studies, anthropogenic landscape studies, neoecology), as well as between ecology and noosphereology (in the concept of noosphere ecosystems), among geogra- 
phy, ecology and philosophy (with respect to eco-

geosophy) can be traced.

Table 1. A Comparative Characteristicof Modern Environmental Concepts

\begin{tabular}{|c|c|c|}
\hline Authors of the Concepts & Names of the Concepts & The Main Content \\
\hline M. Holubets & $\begin{array}{l}\text { The concept of geosoci- } \\
\text { osystems, environmental } \\
\text { studies }\end{array}$ & $\begin{array}{l}\text { The need for the integration of natural sciences around } \\
\text { the topical environmental problems, the consideration of } \\
\text { man outside the biosphere (which is an environment for } \\
\text { humans), the cross-cutting nature of the sciences } \\
\text { studying the interaction of man and the biosphere at the } \\
\text { theoretical level (geosociosystemology) and the applied } \\
\text { one (environmental studies) }\end{array}$ \\
\hline G. Denysyk & $\begin{array}{l}\text { Anthropogenic landscape } \\
\text { studies }\end{array}$ & $\begin{array}{l}\text { The virtual absence of natural landscapes within the } \\
\text { developed land of the Earth today, the acquisition of } \\
\text { qualitatively new content by the landscapes in connec- } \\
\text { tion due to their anthropogenic transformation, the need } \\
\text { for their study as anthropogenic geospatial systems }\end{array}$ \\
\hline $\begin{array}{l}\text { V. Nekos, } \\
\text { A. Nekos }\end{array}$ & Neoecology & $\begin{array}{l}\text { Non-traditional approach to ecology from the point of } \\
\text { view of the leading influence of human transformational } \\
\text { activity on ecosystems }\end{array}$ \\
\hline $\begin{array}{l}\text { K. Nemets, } \\
\text { L. Nemets }\end{array}$ & $\begin{array}{l}\text { The concept of } \\
\text { sociogeosystems }\end{array}$ & $\begin{array}{l}\text { Anthropocentric idea of sociogeosystems as geospatial } \\
\text { social formations of different ranks }\end{array}$ \\
\hline O. Topchiev & $\begin{array}{l}\text { The concept of spatial } \\
\text { organization of nature, } \\
\text { population and economy, } \\
\text { intentional paradigm }\end{array}$ & $\begin{array}{l}\text { Consideration of man as a component of nature and at } \\
\text { the same time a researcher who through his cognitive } \\
\text { activity sets subjective target guides for it }\end{array}$ \\
\hline S. Sonko & $\begin{array}{l}\text { The concept of noosphere } \\
\text { ecosystem }\end{array}$ & $\begin{array}{l}\text { Consideration of 'Homo sapiens' as an equal to others in } \\
\text { carrying out his material-energy exchange in the bio- } \\
\text { sphere }\end{array}$ \\
\hline Yu. Kyselov & Ecogeosophy & $\begin{array}{l}\text { Consideration of geospatial structures of the Earth's } \\
\text { world with the account of not only the landscape-ethnic } \\
\text { interaction in the natural environment, but also the type } \\
\text { of nature management and the human-induced } \\
\text { transformation of landscapes caused by it; geosophy of } \\
\text { the explored space }\end{array}$ \\
\hline
\end{tabular}

Consequently, the focus of contemporary environmental studies and the greatest point of growth of the integrated concept of the environment lies at the intersection of geography and ecology. It should be emphasized that we mean unified geography without its traditional division into physical and socio-economic geography, since virtually all branches of modern geography have ecological content: physical (natural) geography studies the natural landscapes that served as the initial material for man in his diverse economic activity; constructive geography develops probable ways of formation of natural and anthropogenic geosystems in ecological equilibrium on the basis of anthropogenically transformed landscapes; socio-economic (public) geography is related to ecology through the doctrine of natural resources and territorial organization of economy. After all, most branches of economic activity have a greater or lesser negative impact on the environment: enterprises and heavy industry, especially mining, as well as motor transport, pollute the air and water environment; agricultural production neglecting environmental requirements and criteria, causes anthropogenic accelera- tion of erosion processes (both sheet wash and linear erosion) and soil contamination due to excessive application of mineral fertilizers and pesticides.

It is worth noting that some of the aboveconcepts have general geographic content (in particular, anthropogenic landscape studies, neoecology, the concept of noospheric ecosystems, ecogeosophy), which gives grounds for considering complex objects that are investigated with their application as integral systems of various geospatial ranks. At the same time, the concept of sociogeosystems has purely sociogeographical content, which also makes objects that are studied within the framework of this concept (sociogeosystems of various spatial ranks) subsystems of integral systems (such as noosphere ecosystems).

After the analysis of the undoubtedly important concepts of environmental studies, the main question of nature management - 'Why does the global environmental problem continue to get worse?' - still remains unanswered. Even recent fundamental treatises on this problem (Yablokov, Levchenko, 2015, 2016, 2017) do not give any 
hope for a constructive solution to it. Thus, the authors give an answer to the question 'What is going on?' in the first article of the series (Yablokov, Levchenko, 2015). The second article gives an unambiguous answer to the question 'Who is to be blamed?' There is no doubt, it is man (Yablokov, Levchenko, 2016). However, the third article of the cycle gives no answer to the question 'What is to be done?' The authors state that 'the contemporary discourse of social evolution, in spite of attempts to unite the enormous amount of facts and ideas in the field of development of human society, is still at the stage of substantiating hypotheses and distinguishing tendencies. All these efforts have not led to the creation of any comprehensive concept yet, not to mention a complete theory' (Yablokov, Levchenko, 2017).

We dare assert that such a concept (the concept of noosphere ecosystems) was developed by one of the authors 15 years ago (Sonko, 2003).

The essence of the concept of noosphere ecosystems is as follows (Sonko, 2010):

1. The main reason for the emergence and aggravation of the global environmental problem is the different development rates of nature and society. The search for and finding the specific Man ecotope and the study of its spatial evolution is a result of spatially and temporally different, or 'separated' in time and in space, states of nature and society. In order to constructively solve 'the global environmental problem', one must radically revise, first of all, the spatial existence of a man as a species , Homo sapiens. With this aim, one must find such areas of the Earth's space, in which the gap in the speeds of nature and society is 'captured', and in future bring them into the necessary correlation.

2. The aspiration for the state of the noosphere (at the present stage — 'sustainable development') with the course of the process of noospherogenesis should be carried out by Man within the spatial boundaries of the social-natural systems, which substantially represent ecosystems and have a double character of the boundaries. That is, these are such synergistic interconnections of natural and social components that are already evolving according to their own laws. Approximation of the territorial organization of society to the noosphere is proposed to be implemented in the form of possible scenarios at different spatial levels (Table 2). The existing strategy for creating an ecosystem should cover the meso- and macro levels. At the micro level, it is also necessary to implement a strategy of combining the boundaries of natural and agroecosystems, coordinated with the noosphere dynamics. Thus, we comply with one of the main conditions of the noosphere development — such a change in the structure and functions of natural ecosystems performed by man keeps them capable of selfreproduction.

3. One of the main noosphere provisions of theecology of Homo sapiens is that this species is an equal participant in the natural matter-energy cycle. But he has expanded the boundaries of his ecological niche due to the advanced timing of natural processes ('time traps', for example, prolonged storage of biomass in refrigerators, canning, etc., instead of their decomposing by reductions immediately after dying), spatial transformation of its ecotope ('space traps', for example, in the form of 'properly' organized crop rotation, contouringreclamation systems of agriculture, etc.). Moreover, such a spatial-temporal transformation has considerably increased the level of the planetary entropy ('information traps' (Sonko, 2003a; 2003b; 2003c; 2003d).

4. Homo sapiens, in the process of his life in the biosphere of theEarth, forms spatial/edaphic systems which are ecologically identical with other types, and similarly participates in the food chains, occupying his trophic level in the ecosystems that are radically rebuilt in terms of space, but are, nevertheless, natural. 'Ecotope' of man goes beyond the limits of the organism level of organization of a species and occupies the population and even the ecosystem level. Therefore, it is more logical to talk about an agroecosystem as a modified ecological niche of Homo sapiens with unclearly defined (moving) spatial boundaries. Therefore, there is no reason to consider the agroecosystem (as well as other noosphere ecosystems) of Homo sapiens as unnatural (variants: 'semi-natural', 'combined', 'artificial', 'anthropogenic', 'technogenic'), based on the presence of 'the second nature', Man. All ecosystems, including anthropoecosystems (or the noospheric ones), are 'primordial'.

5. The uncertainty of the main guidelines of the concept of sustainable development, which in its present manifestation implies the unfair division of the global territory by 'civilized' countries according to ecological functions (Pozdnyakov, Tikunov, Fedotov, 2003; Protopopov, 2003), induces one to seek one's own concept of the noosphere development, based on the necessity of the methodological separation of the idea of reaching the noosphere state by socio-natural systems (sustainable development) and the idea of nature conservation (with the preservation of an anthropocentric attitude towards it). With the aim of approaching sustainable development, the priority development of agroecosystems, as ana-logues of the noosphere ecological niche of Homo Sapiens is viewed. There is a subsequent need to 'insert' the administrativeterritorial division into the agroecosystem's bor- 
ders, because in this case the chorological content of the interaction of nature and society will approach the optimal ones (Sonko, 2010). In order to implement the concept practically, a model of socio-natural interaction was developed. It is based on the principle of spatial rotation of the functions of urban and agroecosystems with the tendency towards not a barrier, but a contact (ecotonic) type of boundaries between natural and anthropic elements. At the same time, the pattern of the interaction between nature and society radically changes from the anthropocentric to the adapted one. Given the main content of the above concept, we must agree with the opinion of $\mathrm{K}$. Losev and V. Gorshkov (Gorshkov, 1995; Losev, 2003) that the main guarantee of 'the noosphere' character of nature management should not be quotas for carbon dioxide emissions (Kyoto Protocol), but the successful support of self-reproduction mechanisms of natural ecosystems in certain countries.

Concerning agroecosystems, according to current estimates, the emission of carbon (as the main contributor to the greenhouse effect) from the world's agriculture exceeds its emissions from the combustion of fossil fuels by $10 \%$ (Losev, 2003). Therefore, modern agriculture is the main contributor to the greenhouse effect, and this impact will continue to grow in the context of the economic and demographic crisis. The practical solution to these contradictions is the rebirth of such communities of people in the countryside, which by the type of their spatial existence would be close to natural ecosystems. Radical changes in the spatial existence of humankind towards the natural economy will help stabilize the population growth, and will make nature management adapted to natural ecosystems (Sonko, 2017).

Noosphericism - is the doctrine of human society based on the noospheric principles, which consist in the comprehensive adaptation of nature management to natural mechanisms (Table 2). There are objective prerequisites for this. Thus, in rural areas of most countries, people are forced to the brink of survival, which urges them to return to the natural economy and the need to harmonize with the natural landscapes in which the family lives. There are new public initiatives of 'returning to nature' such as the ecological movement 'Ringing Cedars of Russia', manufacture of organic products, ecological settlements, etc. The consumption of natural substances and energy and the generation of biowaste are based on ecosystem principles. The consumption of the ecological resource of the planet 'is stretched' in time in order to ensure the proper conditions for future generations' life.

The spatial, ecological and social life of Man becomes a form of combination of local age-long traditions of nature management and the latest technology in which there are no entropy limitations. The result is a gradual return of the energy consumption of the human population to a level of $1 \%$, which is in accordance with the laws of the ecosystem organization of living organism populations. The main ideas of the noosphere, adapted to the balanced nature management, correlate with the above concept of noosphere ecosystems.

\section{Conclusions}

- Activation of the problem of the environmental concept by anthropogeographers testifies to the fundamental integrity of the entire geographic science without its distinct division into natural and social (or physical and economic) geography previously dogmatically proclaimed by the Soviet methodology and ideology.

- A contemporary, adequate concept of the environment has not been developed yet. Its development and final design will require, above all, the rejection of the mechanistic perception of the surrounding world divided into objects and subjects of research.

-Within the framework of the main problem (the global environmental problem) of the article, it is geographers who must indicate in time and space such integrated environmental systems (socionatural systems, the subsystems of which can be presented by natural landscape systems to varying degrees changed byman) that are formed as a result of the joint development of nature and society.

Table 2. Scenarios of Transition to Sustainable Development

\begin{tabular}{|c|c|c|c|c|}
\hline Scenario Elements & Conservative & Centristic & Scientific & Noospheric \\
\cline { 2 - 5 } $\begin{array}{c}\text { The range of the } \\
\text { planet's population } \\
\text { (billion people) }\end{array}$ & $0.5-1.5$ & $8-12$ & $30-50$ & $8-10$ \\
\hline $\begin{array}{c}\text { The nature of ur- } \\
\text { banization }\end{array}$ & $\begin{array}{c}\text { The level of urbaniza- } \\
\text { tion decreases, econet- } \\
\text { works develop instead } \\
\text { of metropolises and big } \\
\text { cities }\end{array}$ & $\begin{array}{c}\text { Gradual stabilization of } \\
\text { the number and size of } \\
\text { cities, as well as the } \\
\text { population of the Earth }\end{array}$ & $\begin{array}{c}\text { The level of urbanization } \\
\text { increases, } \\
\text { big cities ecologize, } \\
\text { including metropolises }\end{array}$ & $\begin{array}{c}\text { The level of urbanization } \\
\text { decreases, cities are pre- } \\
\text { served, but stop playing } \\
\text { the role 'a social crea- } \\
\text { ture net of ecosettle- } \\
\text { ment expands }\end{array}$ \\
\hline The change in the & Decrease by 6-10 & Increase by 2-3 times & Decrease by 10 and & Gets stabilized at the ex- \\
\hline
\end{tabular}




\begin{tabular}{|c|c|c|c|c|}
\hline \begin{tabular}{|c|} 
volume of the \\
world's power con- \\
sumption
\end{tabular} & times & & more times & $\begin{array}{c}\text { isting level, but the struc- } \\
\text { ture of power consumption } \\
\text { changes radically towards } \\
\text { energy-saving }\end{array}$ \\
\hline $\begin{array}{c}\text { The structure of } \\
\text { energetics }\end{array}$ & $\begin{array}{l}\text { RE-based energy (Re- } \\
\text { newable Energy) }\end{array}$ & $\begin{array}{c}\text { Polyenergetics: atomic, } \\
\text { based on RE, thermal }\end{array}$ & $\begin{array}{c}\text { The predominance of } \\
\text { nuclear power }\end{array}$ & $\begin{array}{c}\text { Basic - hybrid and alter- } \\
\text { native; } \\
\text { supporting - atomic. }\end{array}$ \\
\hline $\begin{array}{c}\text { The nature of agri- } \\
\text { culture: }\end{array}$ & Economical & Moderately economical & Over-intensive & Economical and natural \\
\hline $\begin{array}{c}\text { - the share of arable } \\
\text { land }\end{array}$ & Low $(35-40 \%)$ & Moderate (up to $50 \%$ ) & High (over 60\%) & Low $(35-40 \%)$ \\
\hline $\begin{array}{l}\text { - the system of } \\
\text { agriculture }\end{array}$ & $\begin{array}{c}\text { Organic. Mineral fertil- } \\
\text { izers and pesticides are } \\
\text { not used. }\end{array}$ & $\begin{array}{c}\text { Compromise. Mineral } \\
\text { fertilizers and herbicides } \\
\text { are used in moderate } \\
\text { doses. }\end{array}$ & $\begin{array}{l}\text { Intensive. Closed soil, } \\
\text { high doses of mineral } \\
\text { fertilizers, irrigation, } \\
\text { monoculture are widely } \\
\text { used. }\end{array}$ & $\begin{array}{l}\text { Highly adaptive to local } \\
\text { conditions, with a mini- } \\
\text { mum number of energy } \\
\text { subsidies. }\end{array}$ \\
\hline $\begin{array}{c}\text { - the variety of farm } \\
\text { animals and the } \\
\text { type of feeding }\end{array}$ & $\begin{array}{c}\text { High variability, exten- } \\
\text { sive feeding relying on } \\
\text { natural forage grounds, } \\
\text { growth stimulants are } \\
\text { not used. }\end{array}$ & $\begin{array}{l}\text { Moderate diversity, inte- } \\
\text { grated feed rations with } \\
\text { the use of forage from } \\
\text { arable land, growth } \\
\text { stimulants are not used. }\end{array}$ & $\begin{array}{l}\text { Low diversity, intensive } \\
\text { breeding of cattle, pigs, } \\
\text { poultry with arable food, } \\
\text { wide use of growth } \\
\text { stimulants and other } \\
\text { 'biochemistry' }\end{array}$ & $\begin{array}{c}\text { Diversity according to } \\
\text { local traditions, integrated } \\
\text { feeding, adapted to local } \\
\text { conditions (provided that } \\
\text { the share of 'fodder arable } \\
\text { land' is not more than } \\
15 \%) \text {. } \\
\end{array}$ \\
\hline $\begin{array}{l}\text { - transgenic varie- } \\
\text { ties and breeds }\end{array}$ & Not used & Used in moderation & Widely used & $\begin{array}{l}\text { Transgenic and introduced } \\
\text { plants are either excluded } \\
\text { completely or do not sig- } \\
\text { nificantly affect the struc- } \\
\text { ture of cultural phyto- and } \\
\text { zoocenosis. }\end{array}$ \\
\hline $\begin{array}{l}\text { - the peculiarities of } \\
\text { agricultural prod- } \\
\text { ucts' consumption }\end{array}$ & $\begin{array}{c}\text { Mostly no animal pro- } \\
\text { tein consumption in } \\
\text { favour of the vegetable } \\
\text { one }\end{array}$ & $\begin{array}{l}\text { The diet is close to the } \\
\text { current one }\end{array}$ & $\begin{array}{l}\text { The diet is 'distorted' } \\
\text { towards the further in- } \\
\text { crease in the consump- } \\
\text { tion of animal protein }\end{array}$ & $\begin{array}{l}\text { The diet is balanced and } \\
\text { meets local traditions }\end{array}$ \\
\hline $\begin{array}{c}\text { The main structural } \\
\text { materials (and min- } \\
\text { eral resources) }\end{array}$ & Secondary & $\begin{array}{c}\text { Primary and secondary } \\
\text { with the development of } \\
\text { resource-saving tech- } \\
\text { nologies }\end{array}$ & $\begin{array}{c}\text { Replacement of finite } \\
\text { resources with their new } \\
\text { equivalents }\end{array}$ & $\begin{array}{c}\text { Replacement of finite } \\
\text { lexhaustable resources } \\
\text { with their new equivalents } \\
\text { that will be capable of } \\
\text { biodegradation upon com- } \\
\text { pletion of use }\end{array}$ \\
\hline $\begin{array}{c}\text { Environmental pollu } \\
\text { tion }\end{array}$ & $\begin{array}{l}\text { Minimal due to the } \\
\text { closure of all environ- } \\
\text { mentally unfriendly } \\
\text { industries and the im- } \\
\text { plementation of non- } \\
\text { waste technologies }\end{array}$ & At the current level & $\begin{array}{c}\text { Moderate due to low- } \\
\text { waste technologies, im- } \\
\text { proved treatment facili- } \\
\text { ties and disposal of espe- } \\
\text { cially hazardous waste }\end{array}$ & $\begin{array}{l}\text { Minimal due to de- } \\
\text { urbanization, transition to } \\
\text { new construction materi- } \\
\text { als, reduction of the gen- } \\
\text { eral level of consumption } \\
\text { and introduction of a sig- } \\
\text { nificant share (up to } 40 \% \\
\text { of GDP) of the natural } \\
\text { economy. }\end{array}$ \\
\hline $\begin{array}{c}\text { Biodiversity protec- } \\
\text { tion }\end{array}$ & Complete preservation & $\begin{array}{c}\text { Preservation of a larger } \\
\text { part }\end{array}$ & Preservation of $50-70 \%$ & $\begin{array}{c}\text { Gradual withdrawal from } \\
\text { agroecosystems in their } \\
\text { present form in favour of } \\
\text { adapted forms of nature } \\
\text { management }\end{array}$ \\
\hline $\begin{array}{l}\text { The share of pro- } \\
\text { tected natural terri- } \\
\text { tories on the planet }\end{array}$ & $70 \%$ & $33 \%$ & Less than $10 \%$ & $\begin{array}{c}\text { The need for the introduc- } \\
\text { tion of protected areas is } \\
\text { gradually disappearing }\end{array}$ \\
\hline
\end{tabular}

The prospects for the productive development of environmental science are related to the concept of noosphere ecosystems, which has been developed by one of the authors over the past 25 years (Sonko,
1992-2018) and can become anintegral part of the content of ecogeosophy, the theoretical and methodological principles of which have been improved in treatises of another author (Kyselov, 2015). 


\section{References}

ArskyF. N., 2015. Yesli by ne bylo Strabona [IfStrabodidn't exist]. http://booksonline.com.ua/view.php?book=87675 . (In Russian).

Denysyk H. I., 2001. Lisopole Ukrayiny : Monohrafiya [The "forest-and-field" of Ukraine: A monograph]. Tezys, Vinnytsya. 264 p. (In Ukrainian).

Gorshkov V. G., 1995. Fizicheskiye i biologicheskiye osnovy ustoychivosti zhizni [Physical and biological fundamentals of the sustainable life]. VINITI, Moscow. 470 p. (In Russian).

Gumilev L. N., 2006. Etnogenez i biosfera Zemli [Ethnogenesis and the Earth's biosphere]. - AirisPress, Moscow. 558 p. (In Russian).

Hettner A., 1927. Die Geographie, ihre Geschichte, ihr Wesen und ihre Methoden [Geography, its history, being and methods]. - Ferdinand Hirt, Breslau. 463 S. (In German).

Holubets M. A., 2015. Seredovyshcheznavstvo - v heohrafichnu nauku [Environmental studies - to the geographical science]. Ukrainian Geographical Journal. - \#2. 10-15. (In Ukrainian).

KovalyovO. P., 2014.Zahalnaheohrafiya: yakoyuyerealnist, yaku, yakvvazhayutheohrafy, vonydoslidzhuyut? [General geography: whatistherealitythat, asthegeographers consider, they research?] /http://www.geography.pp.ua/2014/12/blogpost_8.html\#more. (In Ukrainian).

Kyselov Iu. O., 2011. Osnovy heosofiyi: problemy teoriyi ta metodolohiyi [Fundamentals of geosophy: issues of the theory and methodology]. SF "Luhansk Taras Shevchenko National University", Luhansk. 208 p. (In Ukrainian).

KyselovIu. O., 2015. Doformuvannyanaukovykhzasadekolohichnoyiheosofiyi [Onshapingscientificfundamentalsofecologicalgeosophy] HeraldoftheChernivtsiYuriyFedkovychNationalUniversity. Ser. Geogr. - \#762-763. 28-33.(In Ukrainian).

Kyselov Iu. O., 2017. Deyaki terminolohichni aspekty problemy antropohennoho peretvorennya landshaftu [Some terminological aspects of the issue of the anthropogenic transformation of landscape]. Ecology - ways of harmonization of the relations between nature and society. Uman. 1214. (In Ukrainian).

Losev K. S., 2003. Byudzhet antropogennogo ugleroda i rol ekosistem v yego emissii i stoke $\mathrm{v}$ globalnom $\mathrm{i}$ kontinentalnom masshtabe [The budget of anthropogenic carbon and the role of ecosystems in its emission and flow in the global and continental scales]. Countries and regions on the way to sustainable development. Akademperiodika, Kyiv. 36-41. (In Russian).

Nekos V. Yu., Nekos A. N., Safranov T. A., 2011. Zahalna ekolohiya ta neoekolohiya: pidruchnyk dlya studentiv ekolohichnykh spetsialnostey vyshchykh navchalnykh zakladiv [General ecology and neoecology: a textbook for the students of ecological specialties in higher educational institutions]. Kharkiv Vasyl Karazin National University, Kharkiv. 596 p. (In Ukrainian).
Nyemets K. A., NyemetsL. M., 2014.Teoriya I metodolohiya heohrafichnoy inauky: metod yprostorovohoanalizu [Theory and methodology of the geographical science: methods of spatial analysis]. Kharkiv Vasyl Karazin National University, Kharkiv.172 c.(In Ukrainian).

NikolayevV. A., 2006.Garmonicheskiye kanony prirody [The harmonic can on softhenature]. Herald of the Moscow University. Ser. 5. Geography. - \#4. 8-14. (In Russian).

Pozdnyakov D. V., TikunovV. S., Fedotov A. P., 2003.Razrabotka I kartografirovaniye integralnykh pokazateley ustoychivogo razvitiya stranmira [Creating and cartographingintegralindexes of sustainable development of the countries of the world]. Herald of the Moscow University. Ser. 5. Geography. \#2. 20-29. (In Russian).

Protopopov P., 2014. Biokorellirovannaya paradigma razvitiya (elektronnyi resurs) [The bio-correlated paradigm of development (An electronic resource)] http://images. yandex.com/yandsearch ource $=$ wiz $\& f p=0 \&$ text $=$ исий ротопопов $(\mathrm{In}$ Russian).

Pylypenko I. O., 2015.Suspilno-heohrafichna peryferiya: kontseptsiya, parametry zatsiyaidelimitatsiya : Monohrafiya [Socialandgeographicalperiphery: aconception, parameterization and delimitation : A monograph]. Hrin DS, Kherson. (In Ukrainian).

Reteyum A. Yu., 1988. Zemnyye miry [Earth realms]. Mysl, Moscow. 272 p.http://geoman.ru/books/item/f00/s00/z0000078/ index.shtml. (In Russian).

Sonko S. P., 2018. Spysok naukovykh i naukovometodychnykh prats profesora Sonka S. P. stanom na 1.01.17. Pozytsiyi: $29,31,45,46,47,48$, 49, 51, 52, 54, 57, 58, 61, 63, 65, 68, 70, 71, 73, $74,78,86,90,93,94,97,103,124,125,134$, $141,142,164,178,187$ [The list of scientific and scientific and methodical works by Professor S. P. Sonko as of 1.01.17. Positions: 29, 31, 45, 46, $47,48,49,51,52,54,57,58,61,63,65,68,70$, $71,73,74,78,86,90,93,94,97,103,124,125$, $134, \quad 141, \quad 142, \quad 164, \quad 178, \quad 187]$ /http://lib.udau.edu.ua/handle/123456789/5320. (InUkrainian).

Sonko S. P., 2003.Prostorovyi rozvytok sotsiopryrodnykh system: shlyakh donovoy I paradyhmy: Monohrafiya [Spatial development of the social and natural systems: the way to anew paradigm: A monograph]. Nika-Tsentr, Kyiv. 287 p. / http://lib.udau.edu.ua/handle/123456789/367.(In Ukrainian).

Sonko S. P., 2003.Heohrafichna interpretatsiya dopovidey Rymskomuklubu [A geographical interpretation of the reports to the Club of Rome ]. Ukrainian Geographical Journal. № 1. 55-62. (In Ukrainian).

Sonko S. P., 2003.Prostorovi doslidzhennya infrastruktury velykohomista dlya rozrobky kontseptsiyiinfraeko system (na prykladi Kryvoho Rohu) [Spatial researches on the infrastructure of agreatcity for creating a conception of infraecosystems (on 
the example of Kryvyi Rih)].Economic and Social Geography. \#54. 188-197. (In Ukrainian).

Sonko S. P., 2003. Regionalizatsiya, prykordonni konflikty ta maybutni shlyakhy rozvytku pryrody i suspilstva [Regionalization, boundary conflicts and future ways of development of nature and society]. Countries and regions on the way to sustainable development. (In Ukrainian).

Sonko S. P., 2010. Kontseptsiya noosfernykh ekosystemya $\mathrm{k}$ prodovzhennya idey V. I. Vernadskoho [The conception of noospheric ecosystems as continuation of V. I. Vernadsky'sideas]. Noosphere and civilization. All-Ukrainian Philosophical Journal. \#8-9 (11). 230-241. (In Ukrainian).

Sonko S. P., 2011.Heohrafichna nauka v novykh sotsialno-ekonomichnykh umovakh rozvytku Ukrayiny [The geographical science in new social and economic conditions of development of Ukraine]. Constructivism in the modern geography. Ukrainian Geographical Journal. \#1. 32-33. / http://lib.udau.edu.ua/handle/123456789/388. (InUkrainian).

Sonko S. P., MaksymenkoN. V., 2013. Prostorovi i chasovi mekhanizmy ekolohichnoyi ekspansiyi agrolandshaftu [Space and time mechanisms of the ecological expansion of agrarian landscape]. Human and environment. \#2(15). Kharkiv : Kharkiv Vasyl Karazin National University. 5-21. / http://lib.udau.edu.ua/handle/123456789/351. (In Ukrainian).

Sonko S. P., Kyselov Iu. O., 2014.Landshaftno-etnichna vzayemodiya yak metodolohichna problema ekolohiyi [Landscape and ethnical cooperation as a methodological issue of ecology]. Ecology ways of harmonization of relations between nature and society. Uman : Uman National University of Horticulture. 9-13. / http://lib.udau.edu.ua/handle/123456789/536. (In Ukrainian).

Sonko S. P., Maksymenko N. V., Kyselov Iu. O., Mezentsev K. V., 2015. Ekolohichni osnovy udoskonalennya administratyvno-terytorialnoho ustroyu Ukrayiny [Ecological fundamentals of optimization of the administrative and territorial order of Ukraine]. Uman : Uman National University of Horticulture.

http://lib.udau.edu.ua/handle/123456789/6195. (InUkrainian).

Sonko S. P., 2015.QUO VADIS, vitchyznyanasuspilnaheohrafiya? [QUO VADIS, native human geography?]. Up-to-date issues of development of the geographical science and education in Ukraine Kyiv : Obriyi. 51-53. http://lib.udau.edu.ua/handle/123456789/901. (In Ukrainian).

Sonko S. P., MaksymenkoN. V.. 2016. Pro "pryrodnist" ta "antropohennist" landshaftotvorennya [Aboutthe "naturality" andthe "anthropogenity" oflandscapeshaping]. Human and environment. Issues of neoecology. Modern geographical and ecological researches of environment. \#1-2(25). Kharkiv : Kharkiv Vasyl Karazin National University.

9-13. http://lib.udau.edu.ua/handle/123456789/2783. (In Ukrainian).

Sonko S. P., Yamchuk P. M., Kyselov Iu. O., Sukhanova I. P., 2016. Vzayemozvyazok rozvytku agrarnoyi haluzi i metodolohiyi agrarnoyi nauky v umovakh postindustrialnoyi ekonomiky (u konteksti perekhodu na novi standarty vyshchoyi osvity) [Interconnection of development of the agrarian branch and the methodology of the agrarian science in the conditions of post-industrial economy (in the context of passage to the new standards of higher education)].Social and economic aspects of sustainable development of the Ukrainian economy: A collective monograph. Uman : Sochynsky M. M. $122-134$. http://lib.udau.edu.ua/handle/123456789/2639. (InUkrainian).

Sergiy Sonko, 2016. The concept of spatial redistribution in modern subject field of social geography.JournalofSocialandEconomicGeography. \#21 (2). Kharkiv : KharkivVasylKarazinNationalUniversity.12-18.

Sonko S. P., KazakovaT. A., 2016. Chytrebazapovidaty antropohennil and shafty (postneklasychnyi pohlyad na sklad natsionalnoyi ekolohichnoyi merezhi) [Is it necessary to reserve anthropogenic landscapes (a post-non-classical view on the structure of the national ecological network]. Perspectives of the development of forestry and landscape gardening. Uman : Vizavi. 18-20. (In Ukrainian).

Sonko S. P., 2017. Biosferotsentryzm u suchasnykh kontseptsiyakh vzayemodiyi pryrody i suspilstva [Biospherocentrism in the modern conceptions of collaboration between nature and society]. An ecological strategy of the future. Umanhttp://lib.udau.edu.ua/handle/123456789/61 64 (In Ukrainian).

Sonko S. P., 2018. Stalyi rozvytok: 25 rokiv nadiy ta rozcharuvan [Sustainable development: 25 years of hope and disappointment]. Sustainable development- state and perspectives. Lviv : Lviv Polytechnics publishers. 59-63. http://lib.udau.edu.ua/handle/123456789/6620. (In Ukrainian).

TopchievO. H., 2004.Pro predmetnu oblastipredmetsuspilnoyiheohrafiyi [Aboutthesubjectareaandthesubjectofgeography]. Ukrainian GeographicalJournal. № 2. 3-7. (InUkrainian).

TopchievO. H., NudelmanV. I., RudenkoL. H., 2012. Heohrafiyaperednovitnimyvyklykamyizapyt amy (ukrayinskyiaspekt) [Geographyinthe face ofthenewestchallengesandrequirements(Ukrainianaspect)]. Ukrainian Geographical Journal. № 2. 3-10. (InUkrainian).

TopchievO. H., Malchykova D. S., 2014. Planuvannyaterytoriy [Planningofterritories]. Hrin D. S., Kherson. 268 p. (In Ukrainian).

Topchiev O. H., Malchykova D. S., Pylypenko I. O., Yavorska V. V., 2017. Kontseptsiya dovkillya suchasnyi napryam integratsiyi pryrodnycho- ta suspilno-heohrafichnykh doslidzhen [The conception of environment as a modern branch of integration natural- and social and geographical re- 
searches]. Ukrainian Geographical Journal. \#3. 64-70. (InUkrainian).

VernadskyV. I., 1991.Nauchnaya mysl kak planetnoye yavleniye [Scientificthoughtasaplanetaryphenomenon]. Nauka, Moscow. 270 p. (In Russian).

Yablokov A., Levchenko V., 2015.The decision exists: transition to controlled evolution of the biosphere / The Journal of Philosophy and Cosmology. Vol. 14. $92-118$.
Yablokov A., Levchenko V., 2016.The biosphere as a living system. On peculiarities of the evolutionary process on the biosphere level / The Journal of Philosophy and Cosmology. Vol. 17. 152-175.

Yablokov A., Levchenko V., 2017.The Biosphere as a Living System 1. On the Harmonization of $\mathrm{Hu}-$ man and Biosphere Relationship / The Journalof Pphilosophy and Cosmology. Vol. 18. 52-83. 